if the peptide was given one hour after the NMDA.

But will this strategy work in vivo? After showing that the peptide could enter the brain when injected intraperitoneally in rats, the authors tested whether it could reduce the harmful effects of transient middle cerebral artery occlusion (MCAO) - a commonly used model of stroke. Injection of the peptide either before or one hour after the onset of MCAO not only reduced the volume of the resulting infarct, but also significantly reduced the severity of neurological symptoms (postural reflex and forelimb placing deficits) caused by the occlusion.

This work presents exciting possibilities for developing new treatments for stroke. Although much work will be needed to ensure that suppressing signalling downstream of the NMDA receptor has no harmful side effects, there is cause for optimism.

Rachel Jones

(2) References and links ORIGINAL RESEARCH PAPER Aarts, M. et al. Treatment of ischemic brain damage by perturbing NMDA receptor-PSD-95 protein interactions. Science 298, 846-850 (2002)

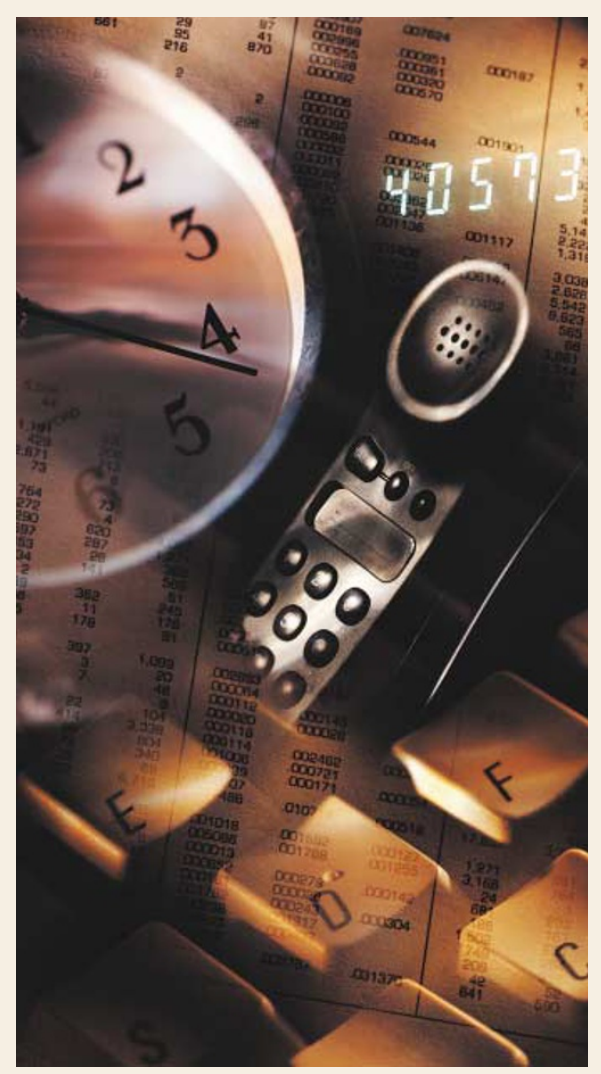

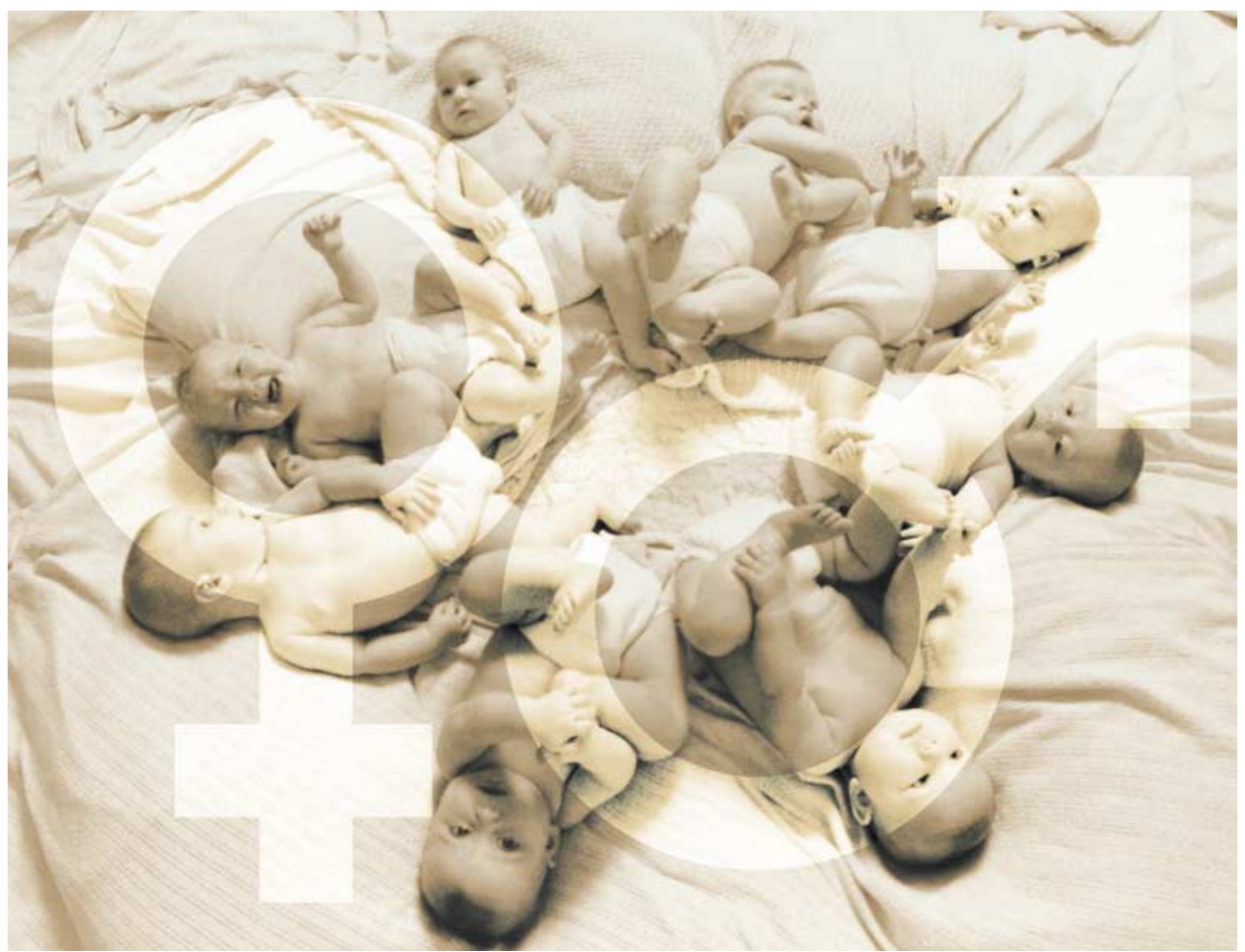

\section{MODEL SYSTEMS}

\section{The genetics of Venus and Mars}

Delving into the minds of men and women can be a profitable enterprise, as the authors of bestsellers such as Men Are from Mars, Women Are from Venus would no doubt testify. Neuroscientists have also taken a keen interest in male-female differences - or dimorphisms - in the brain, but usually to answer more fundamental scientific questions than why men leave the lavatory seat up, or why women take so long to get dressed. In the Journal of Neuroscience, De Vries et al. report on a new transgenic mouse model for studying the genetic basis of sexual dimorphism.

Sexual dimorphism in the brain can take many forms, from variations in the sizes of various structures to differences in behaviour. Sex hormones exert a strong influence on the brain, both during development and throughout life, so it has been assumed that most masculine or feminine brain characteristics are acquired secondary to testis or ovary development. However, De Vries et al. proposed that there might be genes on the sex chromosomes that affect the brain directly, so they created a mouse model that would help them to identify these factors.

Testis development depends on a single gene on the $\mathrm{Y}$ chromosome - the Sry gene. In the absence of $S r y$, ovaries develop by default. The authors generated a transgenic mouse line in which Sry was moved from the $\mathrm{Y}$ chromosome to an autosome. By performing various intercrosses between these and wild-type mice, they obtained XY 'females' (designated $\mathrm{XY}^{-}$), XX' 'males' (XXSry), and XY males with Sry on an autosome instead of the $Y$ chromosome (XY-Sry). They compared XXSry males with $\mathrm{XY}^{-} S r y$ animals rather than wild-type males, to control for the possibility that Sry functions differently in the context of an autosome.

Consistent with previous findings, most structural and behavioural dimorphisms were determined by whether the mouse had testes or ovaries. However, when they compared the density of vasopressin-immunoreactive (VP-ir) fibres in the brains of their mice, they made an intriguing discovery. Normally, males have a higher density of VP-ir fibres in the septum than females, and the $\mathrm{XY}^{-}$Sry mice had a higher density of fibres than XXSry mice, even though the XXSry mice had testes. Similarly, the $\mathrm{XY}^{-}$mice had a higher density of fibres than normal XX mice, even though both had ovaries. These findings indicate that this characteristic is influenced by factors other than Sry on the sex chromosomes.

De Vries et al. speculate that three types of gene could be responsible for non-hormonally induced sexual dimorphisms - genes on the $\mathrm{Y}$ chromosome, $\mathrm{X}$-linked genes that escape $\mathrm{X}$-inactivation, and $\mathrm{X}$-linked genes whose activity is modified by maternal or paternal imprinting. The influence of the sex chromosomes on behaviour has important sociological as well as scientific implications; for example, men with an extra copy of the $\mathrm{Y}$ chromosome show a tendency towards aggressive and criminal behaviour. Is this simply the result of too much testosterone, or would an extra copy of the $\mathrm{Y}$ chromosome minus the Sry gene have a similar effect on behaviour? The new mouse model provides a powerful means of addressing this and other important questions about sexually dimorphic traits.

Heather Wood

(2) References and links

ORIGINAL ReSeARCh PAPER De Vries, G. J. et al. A model system for study of sex chromosome effects on sexually dimorphic neural and behavioural traits. J. Neurosci. 22, 9005-9014 (2002) 